\title{
The effect of seasonal thermal stress on milk production and milk compositions of Korean Holstein and Jersey cows
}

\author{
Dong-Hyun Lim ${ }^{1}$, Vijayakumar Mayakrishnan ${ }^{1}$, Kwang-Seok Ki ${ }^{1}$, Younghoon $\mathrm{Kim}^{2}{ }^{2 *}$, and Tae-II Kim ${ }^{1, *}$
}

\author{
* Corresponding Authors: \\ Younghoon Kim \\ Tel: +82-02-880-4808, Fax: +81-02-873-2271, \\ E-mail: ykeys2584@snu.ac.kr \\ Tae-II Kim \\ Tel: +82-41-580-3388, Fax: +81-41-580-3419 \\ E-mail: kimti@korea.kr
}

${ }^{1}$ Dairy Science Division, National Institute of Animal Science, Rural Development Administration, Cheonan 31000, Korea

${ }^{2}$ Department of Agricultural Biotechnology and Research Institute of Agriculture and Life Science, Seoul National University, Seoul 08826, Korea

ORCID

Dong-Hyun Lim

https://orcid.org/0000-0002-8575-0198

Vijayakumar Mayakrishnan

https://orcid.org/0000-0002-6437-1463 Kwang-Seok Ki

https://orcid.org/0000-0003-0971-1389

Younghoon Kim

https://orcid.org/0000-0001-6769-0657

Tae-II Kim

https://orcid.org/0000-0003-0532-6010

Submitted Dec 4, 2019; Revised Feb 4, 2020; Accepted May 9, 2020
Objective: In this study we investigated the effect of seasonal thermal stress on milk production and milk compositions between Holstein and Jersey dairy cows under the temperateclimate in Korea.

Methods: A total of 9 Holstein lactating dairy cows (2.0 \pm 0.11 parity) which had a daily milk yield of $29.77 \pm 0.45 \mathrm{~kg}$, and days in milk of $111.2 \pm 10.29$ were selected similarly at the beginning of the experiments in each season. Also, a total of 9 Jersey lactating dairy cows $(1.7 \pm 0.12$ parity) which had a daily milk yield of $20.01 \pm 0.43 \mathrm{~kg}$, and days in milk of $114.0 \pm$ 9.74 were selected similarly at the beginning of the experiments.

Results: Results showed that the average ambient temperature $\left({ }^{\circ} \mathrm{C}\right)$ and temperature-humidity index (THI) were higher in summer, and were lower in winter $(\mathrm{p}<0.05)$. The average relative humidity $(\mathrm{RH}, \%)$ was higher in autumn than that of other seasons $(\mathrm{p}<0.05)$. Milk production was significantly decreased (Holstein $29.02 \mathrm{~kg} / \mathrm{d}$ and Jersey $19.75 \mathrm{~kg} / \mathrm{d}$ ) in autumn than in other seasons (Holstein $30.14 \mathrm{~kg} / \mathrm{d}$ and Jersey $20.96 \mathrm{~kg} / \mathrm{d}$ ). However, the milk production was negatively correlated in Holstein cows, and positively correlated in Jersey cows with THI values increased from 16 to 80 . In addition, milk yield was increased by $15 \%$ in Holstein cows and decreased by $11 \%$ in Jersey cows with the THI values increased from 16 to 20 . The fat and protein content percentage was significantly higher in Jersey milk than in Holstein milk, furthermore the fat and protein content yield was higher in Jersey cow milk than that of Holstein cow's milk with all THIs.

Conclusion: From the study results, we concluded that Jersey cows might be less adaptable to low temperature of the winter, and this would have a negative impact on dairy farmer income since Korea's milk price estimation system places a higher value on milk yield than on milk compositions or sanitary grades.

Keywords: Milk Production; Season; Temperature-humidity Index; Milk Composition

\section{INTRODUCTION}

Climate change is transforming the earth ecosystems, and such change is producing a series of damaging abnormal weather phenomena, with the summer prolonged and the temperature relatively increasing in the world [1]. Early research demonstrated that the increasing trend of mean $/ \mathrm{max} / \mathrm{min}$ surface temperature is evident during the summer season in Korea [2].

Heat stress (HS) is one of the most significant challenges to milk production facing dairy farmers during the summer. Climatic conditions in the Korean peninsula are such that the summer season is relatively hot, and generally accompanied by high relative humidity (RH). Thus HS is chronic in nature, there is often little relief from the heat during the evening hours, and intense bursts of combined temperature and humidity further depress performance. Lactating dairy cows produce a large quantity of metabolic heat and accumulate additional heat from radiant energy. Production and accumulation of heat, 
coupled with compromised cooling capability because of environmental conditions, causes heat load in the cow to increase to the point that body temperature rises, intake declines and ultimately the cow's milk productivity declines [3].

In addition, as breeders select for higher milk production, they can mistakably also select for cows with less heat tolerance. Jersey breed is the second most important dairy breed in the world, the Jersey breed is smaller than Holstein breed, and their feed consumption is less than that of Holstein cows [4]. Besides, the faecal output, carbon gases emission, and space need for the breeding of Jersey cows are lower than that of Holstein cows [4,5]. Therefore, Jersey breeding is relatively beneficial to dairy farmers. Early research also demonstrated that as measured by milk yield Jersey cows might have more heat tolerance than Holstein cows [6]. For all these reasons, the dairy farmers and industries have a growing interest in raising Jersey breed. However, the relationship between breed and responses to seasonal HS has not been studied in Korea. Therefore, the objective of the current experiment was to evaluate the effects of seasonal changes on milk production and milk composition of Jersey breed compared with Holstein breed in Korea.

\section{MATERIALS AND METHODS}

\section{Animals, management and experimental design}

The study was conducted at the Department of Animal Resources Development, National Institute of Animal Science (NIAS), Cheonan, Republic of Korea (36 $55^{\circ} 53.2^{\prime \prime}$ North, $127^{\circ} 06^{\prime} 22.1^{\prime \prime}$ East, $23 \mathrm{~m}$ altitude). All dairy cows were maintained as stated in standard guidelines, and the experimental protocol involved in this research was approved by the Institutional Animal Care and Use Committee (IACUC) at National Institute of Animal Science, Jeonju, Republic of Korea. A total of 9 Holstein lactating dairy cows $(2.0 \pm 0.11$ parity) which had a daily milk yield of $29.77 \pm 0.45 \mathrm{~kg}$, and days in milk of $111.2 \pm 10.29$ were selected similarly at the beginning of each season. Also, a total of 9 Jersey lactating dairy cows ( $1.7 \pm 0.12$ parity) which had a daily milk yield of $20.01 \pm 0.43 \mathrm{~kg}$, and days in milk of $114.0 \pm 9.74$ were selected similarly at the beginning of the season. The experiment was carried out from January 2016 to July 2017. The cows were raised under the same management and environmental conditions and housed in an open loose barn. The loose open barn was designed with the overshot roof of a ridge exhaust, fans to move and exchange the air in summer, and winch-curtain to block the cold wind in winter. The total mixed ration (TMR) was offered once a day at 09:00 h. The composition of the TMR remained the same throughout the year and included corn silage $28.1 \%$, mixed hay $14.6 \%$, alfalfa hay $8.3 \%$, concentrate mixture $39.1 \%$, soybean meal
$4.4 \%$, corn grain $4.4 \%$, and mineral and energetic components $1.0 \%$. The TMR contained, on average, $47.3 \%$ dry matter (DM), 16.6\% crude protein (CP), 4.96\% ether extract (EE), 38.7\% neutral detergent fiber (NDF), and 19.5\% acid detergent fiber (ADF) on a DM basis. The percentages of DM, CP, and crude fiber in oat silage were $28.5 \%, 6.7 \%$, and $35.1 \%$ and $30,7.11 \%$, and $34 \%$ for the spring and summer periods, respectively. The energy content of feed rations of all cows was $1.7 \mathrm{Mcal}$ net energy of lactation/ $\mathrm{kg} \mathrm{DM}$ and total digestible nutrients $68.7 \%$. TMR samples were taken monthly and stored at $-20^{\circ} \mathrm{C}$ until analysis. Feeding was allowed throughout the 24 -hour period. Drinking water was made available at all times.

\section{Measurement, sampling, and laboratory analysis}

The ambient temperature $\left(\mathrm{Ta},{ }^{\circ} \mathrm{C}\right)$ and $\mathrm{RH}(\%)$ was monitored with a thermo-hygrometer (Testo $174 \mathrm{H}$, Testo Inc., West Chester, PA, USA) with an accuracy of $\pm 0.5^{\circ} \mathrm{C}$, and $\pm 3 \% \mathrm{RH}$. The thermo-hygrometer was set to record every day per 30 minutes and placed in the feeding area at a height of 2 meters above the ground. The temperature and humidity values were used to calculate several THI values; THI was calculated for each $30 \mathrm{~min}$ temperature and humidity measurement according to the formula: $\mathrm{THI}=\left(0.8 \times{ }^{\circ} \mathrm{C}\right)+(\mathrm{RH}$ $\left.\% \times\left[{ }^{\circ} \mathrm{C}-14.4\right]\right)+46.4$ [7]. The mean daily THI forms the mean of all available 30 minutes THI's per day. The maximum THI values for everyday were calculated according to the same formula of Fox and Tylutki [8], with the maximal temperature and the minimum $\mathrm{RH} / \mathrm{d}$, and the minimum THI values for everyday were calculated with the minimum temperature and the maximum RH/d.

TMR samples were analyzed for DM, CP, and EE by AOAC (1995) procedure, and NDF and ADF by Van Soest et al [9]. The cows were milked two times a day (06:00 and 17:00 h) and milk yield of the individual cows was recorded at each milking on all experimental periods. Milk samples were collected from each cow twice daily at morning (06:00 h) and afternoon (17:00 h) biweekly, and was analyzed for protein, fat, and somatic cells using with a LactoScop (MK2, Delta Instruments, Drachten, the Netherlands).

Milk yield and milk protein and fat percentage were used to calculate the fat protein corrected milk (FPCM) yield [10]. The yields of milk fat and protein were calculated from milk yield and the contents of milk fat and protein, respectively.

\section{Statistical analysis}

The data analysis was performed with the statistical package SAS Enterprise Guide 7.1 (SAS Institute Inc., Cary, NC, USA). Seasons were defined as follows: spring (March to May), summer (June to August), autumn (September to November), and winter (December to February). The THI measured during the experimental period was divided into 13 classes 
based on the daily mean as follows: 16 to 20,21 to 25,26 to 30,31 to 35,36 to 40,41 to 45,46 to 50,51 to 55,56 to 60 , 61 to 65,66 to 70,71 to 75 , and 76 to 80 .

The effects of the THIs and seasons on the milk production and milk compositions of each breed (Holstein and Jersey cows) were analyzed by using the one-way analysis of variance (ANOVA). Tuckey's test was used to separate the means when significance was indicated. The effects of a breed and THI, or breed and season on the milk production and milk composition were analyzed by using the mixed procedure with a restricted maximum likelihood model. The breed, THI or season, and their interactions were included as fixed effects. For comparisons between breeds, THIs or seasons, and breed $\times$ THIs or seasons, the $\mathrm{p}$-values after Bonferroni post hoc test adjustment are presented. The values are presented as least-squares means and standard errors of the means unless otherwise stated. Differences were considered significant if a probability ( $p$ ) of $<0.05$ was found, and trends are discussed for variables with $\mathrm{p} \leq 0.10$.

\section{RESULTS}

Meteorological data including the mean minimum and maximum Ta, RH, and THI measured during milk recording of each breed dairy cows in period from 2016 to 2017 are summarized in Table 1 . The recorded average daily Ta and THI were higher in summer $\left(24.02^{\circ} \mathrm{C} \pm 0.05^{\circ} \mathrm{C}, 72.55 \pm 0.09\right)$, and was lower in winter $\left(-1.62^{\circ} \mathrm{C} \pm 0.09^{\circ} \mathrm{C}, 35.11 \pm 0.12\right)$ than that of all other seasons $(\mathrm{p}<0.05)$. The results showed that the average RH was significantly highest in autumn (72.51\%) and was significantly lowest in spring season $(59.75 \%)(\mathrm{p}<0.05)$. The average daily $\mathrm{THI} \geq 72$ was observed to be $0.96 \%$ in the spring, $57.78 \%$ in summer, and $2.11 \%$ in the autumn, which indicates that cows were exposed to the critical point of HS. In contrast, cows experienced the cold stress ( $\mathrm{THI} \leq 38$ ) by $0.48 \%$ in the spring, $2.82 \%$ in the autumn, and $68.86 \%$ in the winter season.
The seasonal thermal stress effects on milk yield and FPCM yield trend between the Holstein and Jersey cows are represented in Table 2 and Figure 1. In Holstein dairy cows, milk production was decreased from the spring $(30.94 \mathrm{~kg} / \mathrm{d})$ to autumn $(29.02 \mathrm{~kg} / \mathrm{d})$, and then increased to winter season $(31.12 \mathrm{~kg} / \mathrm{d})(\mathrm{p}<0.05)$. However, in Jersey cows, milk production was lower in autumn $(19.75 \mathrm{~kg} / \mathrm{d})$ and winter $(19.90$ $\mathrm{kg} / \mathrm{d})$ season than that of spring $(21.22 \mathrm{~kg} / \mathrm{d})$ and summer season $(20.96 \mathrm{~kg} / \mathrm{d})(\mathrm{p}<0.05)$.

Results in Figure 2 show that the milk production of Holstein was highest $(35.52 \mathrm{~kg} / \mathrm{d})$ at the 16 to 20 among the all THI ranges, then started to decline and remained constant $(29.74$ to $31.10 \mathrm{~kg} / \mathrm{d})$ when the THI values increased from 31 to $80(\mathrm{p}<0.05)$. On the contrary, the milk yield of Jersey cows was lowest $(18.62 \mathrm{~kg} / \mathrm{d})$ at the 16 to 20 among the all THI ranges, and then the milk yield increased (20.63 to 21.22 $\mathrm{kg} / \mathrm{d})$ with a THI of 51 to $80(\mathrm{p}<0.05)$.

The present study has shown the relationship between the milk yield and THI values in Holstein and Jersey cows (Table

Table 2. The effect of seasonal thermal stress on milk production between the Holstein and Jersey cows

\begin{tabular}{|c|c|c|c|c|}
\hline Item & Holstein & Jersey & SEM & p-value \\
\hline & \multicolumn{4}{|c|}{ Milk yield (kg/d per head) } \\
\hline Spring & $30.94^{a, x}$ & $21.22^{\mathrm{a} y \mathrm{y}}$ & 0.17 & $<0.001$ \\
\hline Summer & $30.14^{b, x}$ & $20.96^{a, y}$ & 0.14 & $<0.001$ \\
\hline Autumn & $29.02^{c, x}$ & $19.75^{\mathrm{b}, \mathrm{y}}$ & 0.20 & $<0.001$ \\
\hline \multirow[t]{2}{*}{ Winter } & $31.12^{a, x}$ & $19.90^{b, y}$ & 0.23 & $<0.001$ \\
\hline & \multicolumn{4}{|c|}{ FPCM (kg/d per head) } \\
\hline Spring & $29.82^{b, x}$ & $24.55^{a, y}$ & 0.20 & $<0.001$ \\
\hline Summer & $29.50^{b, x}$ & $23.34^{\mathrm{b}, y}$ & 0.18 & $<0.001$ \\
\hline Autumn & $28.45^{c, x}$ & $22.96^{\mathrm{b}, \mathrm{y}}$ & 0.23 & $<0.001$ \\
\hline Winter & $31.08^{a, x}$ & $22.71^{\mathrm{b}, \mathrm{y}}$ & 0.27 & $<0.001$ \\
\hline
\end{tabular}

SEM, standard error of the mean; FPCM, fat- and protein-corrected milk.

${ }^{a-c}$ denotes comparison made within the same column (comparison between the spring, summer, autumn, winter and Holstein and Jersey cows, respectively) $(p<0.05)$.

${ }^{x, y}$ denotes comparisons made with same row (comparison with Holstein and Jersey cows in the same season) $(p<0.05)$.

Table 1. Environmental conditions during the experimental periods

\begin{tabular}{|c|c|c|c|c|}
\hline \multirow{2}{*}{ Items } & \multicolumn{4}{|c|}{ Season period } \\
\hline & Spring & Summer & Autumn & Winter \\
\hline $\mathrm{Ta}, \mathrm{minimum}\left({ }^{\circ} \mathrm{C}\right)$ & $6.21 \pm 0.11^{c}$ & $19.57 \pm 0.07^{a}$ & $9.21 \pm 0.17^{b}$ & $-7.12 \pm 0.11^{d}$ \\
\hline $\mathrm{Ta}, \mathrm{maximum}\left({ }^{\circ} \mathrm{C}\right)$ & $20.14 \pm 0.12^{c}$ & $29.31 \pm 0.06^{a}$ & $20.66 \pm 0.16^{b}$ & $4.07 \pm 0.11^{d}$ \\
\hline Ta, average $\left({ }^{\circ} \mathrm{C}\right)$ & $13.12 \pm 0.11^{c}$ & $24.02 \pm 0.05^{a}$ & $14.54 \pm 0.16^{b}$ & $-1.62 \pm 0.09^{d}$ \\
\hline $\mathrm{RH}$, minimum (\%) & $29.34 \pm 0.31^{d}$ & $47.72 \pm 0.29^{a}$ & $42.87 \pm 0.37^{b}$ & $35.77 \pm 0.34^{c}$ \\
\hline $\mathrm{RH}$, maximum (\%) & $87.73 \pm 0.59^{c}$ & $90.45 \pm 0.41^{b}$ & $92.11 \pm 0.59^{a}$ & $85.98 \pm 0.75^{d}$ \\
\hline $\mathrm{RH}$, average (\%) & $59.75 \pm 0.26^{d}$ & $71.71 \pm 0.21^{b}$ & $72.51 \pm 0.27^{a}$ & $63.89 \pm 0.29^{c}$ \\
\hline Daily THI, minimum & $46.72 \pm 0.15^{\mathrm{c}}$ & $65.98 \pm 0.10^{a}$ & $50.27 \pm 0.26^{b}$ & $27.21 \pm 0.14^{d}$ \\
\hline Daily THI, maximum & $64.06 \pm 0.14^{c}$ & $76.82 \pm 0.08^{a}$ & $65.75 \pm 0.19^{b}$ & $46.01 \pm 0.12^{d}$ \\
\hline Daily THI, average & $56.19 \pm 0.15^{c}$ & $72.55 \pm 0.09^{a}$ & $58.36 \pm 0.24^{b}$ & $35.11 \pm 0.12^{d}$ \\
\hline
\end{tabular}

$\mathrm{Ta}$, ambient temperature; $\mathrm{RH}$, relative humidity; $\mathrm{THI}$, temperature-humidity index.

${ }^{a-d}$ Denotes comparison made within rows $(p<0.05)$. 

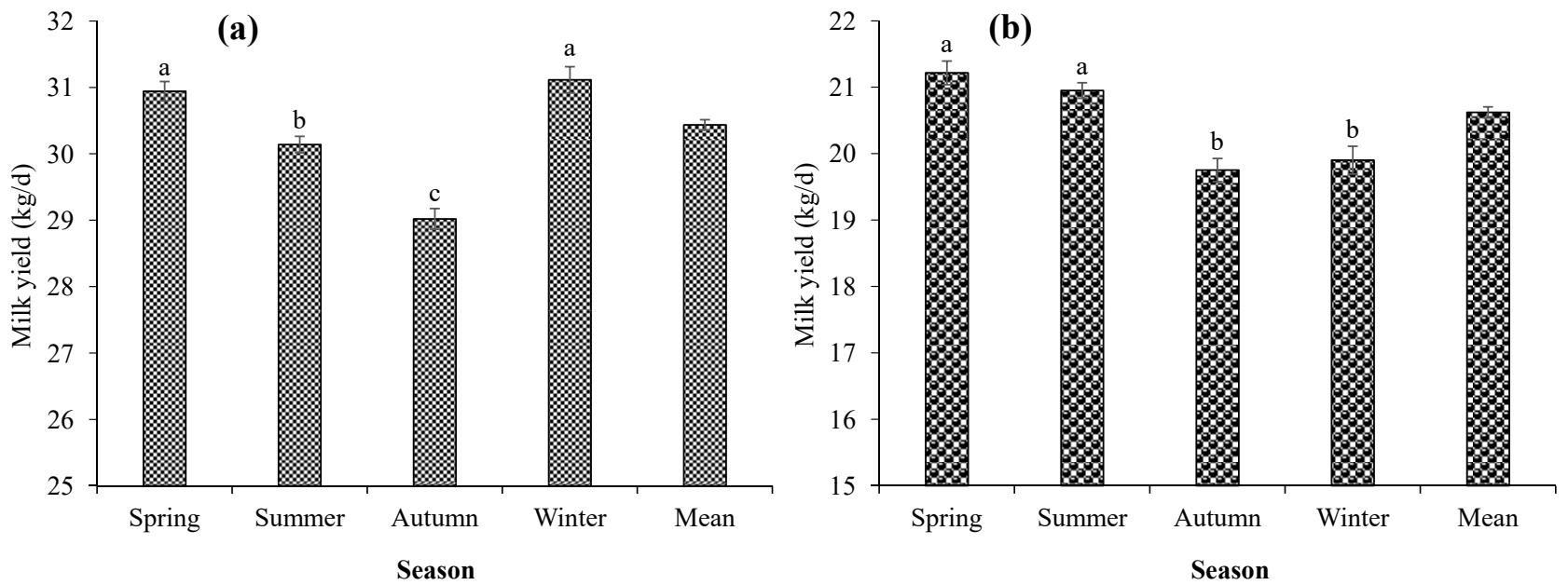

Figure 1. Milk yield of Holstein and Jersey cows against seasonal thermal changes. In Holstein cows, the lowered milk production (a) was observed during autumn season as compared to other seasons. In Jersey cows, the lowered milk production (b) was noted during autumn and winter when compared to other seasons. Values are expressed as mean \pm standard error of the mean. ${ }^{a, b}$ Means with different superscripts in the row indicate significant differences $(p<0.05)$.

3). The average milk yield in Holstein and Jersey cows was decreased by $1 \%$ with a THI of 76 to 80 . The average milk yield in Holstein cows was increased by $7 \%$ to $15 \%$ when the THI values decreased from 26-30 to 16-20. However, milk yield for Jersey cows dropped by $4 \%$ to $5 \%$ for THI values between 21 and 50, and reduced by $11 \%$ when the range of THI is 16 to 20. But the average milk yield was not affected by HS between the Holstein and Jersey cows with a THI val- (a)

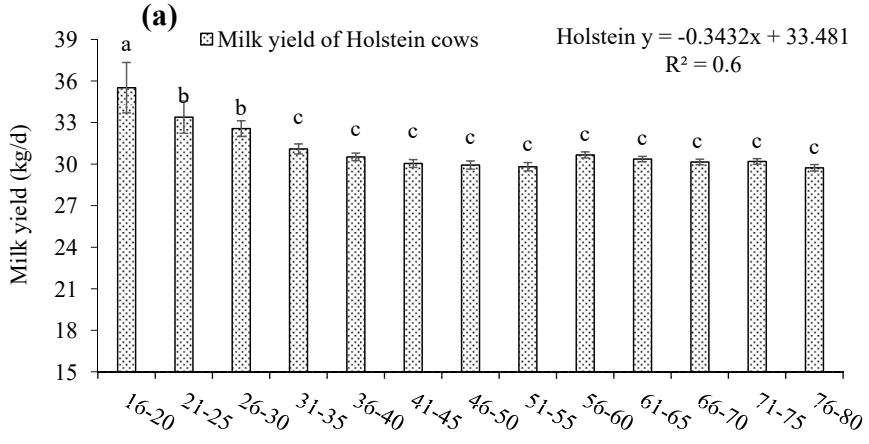

THI

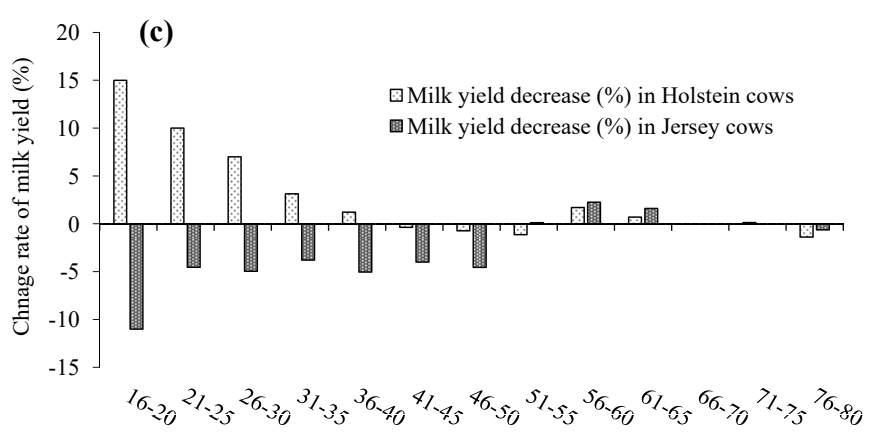

THI

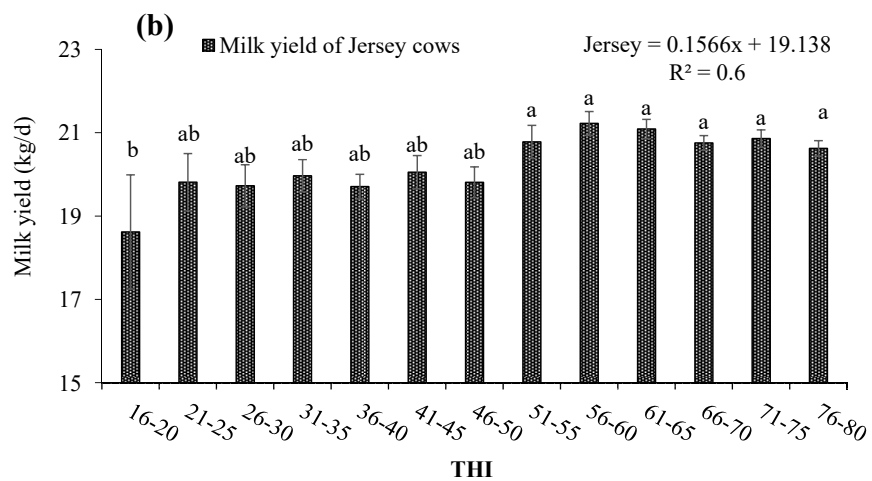

Figure 2. Milk yield and change rate of Holstein and Jersey cows against temperature-humidity index (THI) in Korean seasonal thermal changes. The milk production was negatively correlated in Holstein cows (a), and positively correlated in Jersey cows (b) with THI values increased from 16 to 80 . The milk yield was increased by $15 \%$ in Holstein cows and decreased by $11 \%$ in Jersey cows as the THI values increased from 16 to 80 compared with the THI of 66 to 70 (c). Values are expressed as mean \pm standard error of the mean. ${ }^{\mathrm{a}-\mathrm{c}}$ Means with different superscripts in the row indicate significant differences $(\mathrm{p}<0.05)$. 
Table 3. The effect of temperature-humidity index on milk production and changing rate between the Holstein and Jersey cows based on the temperature-humidity index of 66-70

\begin{tabular}{lccccc}
\hline & \multicolumn{2}{c}{ Holstein } & & \multicolumn{2}{c}{ Jersey } \\
\cline { 2 - 3 } \cline { 5 - 6 } THI & $\begin{array}{c}\text { Milk yield } \\
(\mathbf{k g})\end{array}$ & $\begin{array}{c}\text { Change rate } \\
\mathbf{( \% )}\end{array}$ & & $\begin{array}{c}\text { Milk yield } \\
\mathbf{( k g )}\end{array}$ & $\begin{array}{c}\text { Change rate } \\
\mathbf{( \% )}\end{array}$ \\
\hline $16-20$ & 5.36 & 15 & & -2.14 & -11 \\
$21-25$ & 3.24 & 10 & & -0.95 & -5 \\
$26-30$ & 2.40 & 7 & & -1.03 & -5 \\
$31-35$ & 0.94 & 3 & & -0.79 & -4 \\
$36-40$ & 0.36 & 1 & & -1.05 & -5 \\
$41-45$ & -0.11 & 0 & & -0.71 & -4 \\
$46-50$ & -0.22 & -1 & & -0.95 & -5 \\
$51-55$ & -0.35 & -1 & & 0.02 & 0 \\
$56-60$ & 0.51 & 2 & & 0.46 & 2 \\
$61-65$ & 0.20 & 1 & & 0.33 & 2 \\
$66-70$ & 0.00 & 0 & & 0.00 & 0 \\
$71-75$ & 0.03 & 0 & & 0.10 & 0 \\
$76-80$ & -0.42 & -1 & -0.13 & -1 \\
\hline
\end{tabular}

$\mathrm{THI}$, temperature-humidity index; SEM, standard error of the mean.

ue of 66 to 70 .

The seasonal thermal stress effects on milk composition between the Holstein and Jersey cows are represented in Table 4 . The study results showed that the milk fat percentage was higher in the winter (Holstein 4.19\%, Jersey 5.62\%) among the seasons in all breed's milk $(\mathrm{p}<0.05)$. In Jersey cows, the milk fat percentage was lower $(4.93 \%, \mathrm{p}<0.05)$ in summer than in the other season. However, the milk protein percentage of Holstein cows gradually increased from the spring $(3.21 \%)$ to the winter $(3.44 \%)(\mathrm{p}<0.05)$. However, the milk protein percentage of Jersey cows was increased more in autumn $(3.88 \%)$ and winter (4.00\%) than in spring $(3.75 \%)$ and in summer $(3.52 \%)(\mathrm{p}<0.05)$. In Holstein cows, somatic cell count (SCC) was significantly increased in the summer $\left(160.46 \times 10^{3} / \mathrm{mL}\right)$. But, in Jersey cow, SCC was significantly higher in the autumn $\left(275.07 \times 10^{3} / \mathrm{mL}\right)$.

The effects of THI on the yield of milk fat and protein of Holstein and Jersey cows are presented in Table 5. The milk fat and protein yields were highest in Holstein cows (1.30 to $1.32 \mathrm{~kg} / \mathrm{d}$ and 1.11 to $1.12 \mathrm{~kg} / \mathrm{d}$, respectively) when the THI values increased from 21 to 30 , and were lowest $(1.09 \mathrm{~kg} / \mathrm{d}$ and $0.93 \mathrm{~kg} / \mathrm{d}$, respectively) when the THI ranged from 46 to 50 among the all THI ranges of 21 to $80(\mathrm{p}<0.05)$. In Jersey cows, yield of milk fat was highest $(1.15 \mathrm{~kg} / \mathrm{d})$ at the THI of 31 to 35 , milk protein was highest $(0.79 \mathrm{~kg} / \mathrm{d})$ at THI of 26 to 30 of THI, and lowest milk fat and protein yield was recorded $(1.00 \mathrm{~kg} / \mathrm{d}$ and $0.71 \mathrm{~kg} / \mathrm{d})$ at a THI of 76 to $80(\mathrm{p}<0.05)$.

\section{DISCUSSION}

The average daily $\mathrm{Ta}\left({ }^{\circ} \mathrm{C}\right)$ and $\mathrm{THI}$ were significantly higher in summer and lower in winter when measured data from
Table 4. The effect of seasonal thermal stress on milk composition between the Holstein and Jersey cows

\begin{tabular}{|c|c|c|c|c|}
\hline THI & Holstein & Jersey & SEM & p-value \\
\hline & \multicolumn{4}{|c|}{ Milk fat (\%) } \\
\hline Spring & $3.85^{\mathrm{b}, \mathrm{y}}$ & $5.36^{b, x}$ & 0.04 & $<0.001$ \\
\hline Summer & $3.93^{b, y}$ & $4.93^{\mathrm{c}, \mathrm{x}}$ & 0.03 & $<0.001$ \\
\hline Autumn & $3.91^{\text {b.y }}$ & $5.31^{\mathrm{b}, \mathrm{x}}$ & 0.05 & $<0.001$ \\
\hline \multirow[t]{2}{*}{ Winter } & $4.19^{a, y}$ & $5.62^{a, x}$ & 0.04 & $<0.001$ \\
\hline & \multicolumn{4}{|c|}{ Milk fat $(\mathrm{kg})$} \\
\hline Spring & $1.18^{\mathrm{b}, \mathrm{x}}$ & $1.10^{\mathrm{a}, \mathrm{y}}$ & 0.01 & $<0.001$ \\
\hline Summer & $1.17^{\mathrm{b}, \mathrm{x}}$ & $1.03^{\mathrm{b}, \mathrm{y}}$ & 0.01 & $<0.001$ \\
\hline Autumn & $1.11^{\mathrm{c}, \mathrm{x}}$ & $1.03^{b, y}$ & 0.01 & 0.001 \\
\hline \multirow[t]{2}{*}{ Winter } & $1.28^{\mathrm{a}, \mathrm{x}}$ & $1.10^{\mathrm{a}, \mathrm{y}}$ & 0.01 & $<0.001$ \\
\hline & \multicolumn{4}{|c|}{ Milk protein (\%) } \\
\hline Spring & $3.21^{c}$ & $3.75^{b}$ & 0.02 & $<0.001$ \\
\hline Summer & $3.23^{c}$ & $3.52^{c}$ & 0.01 & $<0.001$ \\
\hline Autumn & $3.34^{\mathrm{b}}$ & $3.88^{\mathrm{a}}$ & 0.02 & $<0.001$ \\
\hline \multirow[t]{2}{*}{ Winter } & $3.44^{\mathrm{a}}$ & $4.00^{a}$ & 0.02 & $<0.001$ \\
\hline & \multicolumn{4}{|c|}{ Milk protein (kg) } \\
\hline Spring & $0.98^{b, x}$ & $0.77^{\mathrm{a}, \mathrm{y}}$ & 0.01 & $<0.001$ \\
\hline Summer & $0.97^{b c, x}$ & $0.73^{\mathrm{b}, y}$ & 0.01 & $<0.001$ \\
\hline Autumn & $0.95^{c, x}$ & $0.76^{a b, y}$ & 0.01 & $<0.001$ \\
\hline \multirow[t]{2}{*}{ Winter } & $1.05^{\mathrm{a}, \mathrm{x}}$ & $0.78^{a, y}$ & 0.01 & $<0.001$ \\
\hline & \multicolumn{4}{|c|}{ Solids (\%) } \\
\hline Spring & $12.42^{\mathrm{C}}$ & $14.30^{c}$ & 0.05 & $<0.001$ \\
\hline Summer & $12.57^{\circ}$ & $13.85^{\mathrm{d}}$ & 0.04 & $<0.001$ \\
\hline Autumn & $12.77^{\mathrm{b}}$ & $14.60^{b}$ & 0.07 & $<0.001$ \\
\hline \multirow[t]{2}{*}{ Winter } & $13.17^{\mathrm{a}}$ & $14.96^{\mathrm{a}}$ & 0.06 & $<0.001$ \\
\hline & \multicolumn{4}{|c|}{ Solids $(\mathrm{kg})$} \\
\hline Spring & $3.81^{b, x}$ & $2.96^{a, y}$ & 0.03 & $<0.001$ \\
\hline Summer & $3.76^{\mathrm{b}, \mathrm{x}}$ & $2.89^{a b, y}$ & 0.02 & $<0.001$ \\
\hline Autumn & $3.65^{\mathrm{c}, \mathrm{x}}$ & $2.85^{\mathrm{b}, y}$ & 0.03 & $<0.001$ \\
\hline \multirow[t]{2}{*}{ Winter } & $4.03^{\mathrm{a}, \mathrm{x}}$ & $2.92^{a b, y}$ & 0.03 & $<0.001$ \\
\hline & \multicolumn{4}{|c|}{ Lactose (\%) } \\
\hline Spring & $4.73^{\mathrm{c}}$ & $4.66^{b}$ & 0.01 & 0.001 \\
\hline Summer & $4.71^{\mathrm{c}}$ & $4.72^{\mathrm{a}}$ & 0.01 & 0.342 \\
\hline Autumn & $4.79^{b}$ & $4.69^{\mathrm{ab}}$ & 0.01 & 0.007 \\
\hline \multirow[t]{2}{*}{ Winter } & $4.85^{\mathrm{a}}$ & $4.68^{\mathrm{ab}}$ & 0.01 & $<0.001$ \\
\hline & \multicolumn{4}{|c|}{ Somatic cell count $\left(\times 10^{3} / \mathrm{mL}\right)$} \\
\hline Spring & $111.76^{b}$ & $97.19^{b}$ & 10.45 & 0.496 \\
\hline Summer & $160.46^{a}$ & $140.44^{b}$ & 12.11 & 0.409 \\
\hline Autumn & $58.62^{c}$ & $275.07^{a}$ & 27.83 & $<0.001$ \\
\hline Winter & $71.53^{\mathrm{c}}$ & $61.61^{b}$ & 4.06 & 0.253 \\
\hline
\end{tabular}

THI, temperature-humidity index; SEM, standard error of the mean.

${ }^{a-d}$ denotes comparison made within the same column (comparison between the spring, summer, autumn, winter season and Holstein and Jersey cows, respectively) $(p<0.05)$.

${ }^{x, y}$ denotes comparisons made with same row (comparison with Holstein and Jersey cows in the same season) $(p<0.05)$.

each seasonal period were analyzed $(\mathrm{p}<0.05)$. However, the average $\mathrm{RH}(\%)$ was highest in autumn $(\mathrm{p}<0.05)$. The THI represents the combination of Ta and $\mathrm{RH}$, and used as a comprehensive indicator to assess the heat and cold stress degree of dairy cows. Some studies have explored the thermoneutral zone which is between $5^{\circ} \mathrm{C}$ and $25^{\circ} \mathrm{C}$ [11], and is within the range of $-0.5^{\circ} \mathrm{C}$ to $20.0^{\circ} \mathrm{C} \mathrm{Ta}$ and $60 \%$ to $80 \% \mathrm{RH}$ [12]. 
Table 5. The effect of temperature-humidity index on milk composition between the Holstein and Jersey cows

\begin{tabular}{|c|c|c|c|c|}
\hline THI & Holstein & Jersey & SEM & $\mathrm{p}$-value \\
\hline & \multicolumn{4}{|c|}{ Milk fat (kg/d per head) } \\
\hline $21-25$ & $1.30^{\mathrm{a}, \mathrm{x}}$ & $1.05^{a b c d, y}$ & 0.05 & 0.004 \\
\hline $26-30$ & $1.32^{\mathrm{a}, \mathrm{x}}$ & $1.12^{\mathrm{ab}, \mathrm{y}}$ & 0.03 & 0.001 \\
\hline $31-35$ & $1.28^{\mathrm{ab}, \mathrm{x}}$ & $1.15^{a, y}$ & 0.02 & 0.011 \\
\hline $36-40$ & $1.27^{\mathrm{ab}, \mathrm{x}}$ & $1.08^{\mathrm{abcd}, \mathrm{y}}$ & 0.02 & $<0.001$ \\
\hline $41-45$ & $1.22^{\mathrm{bc}, \mathrm{x}}$ & $1.02^{\text {bcd,y }}$ & 0.02 & $<0.001$ \\
\hline $46-50$ & $1.09^{e}$ & $1.03^{\mathrm{bcd}, \mathrm{y}}$ & 0.02 & 0.106 \\
\hline $51-55$ & $1.15^{\text {cde }}$ & $1.12^{a b c, y}$ & 0.02 & 0.281 \\
\hline $56-60$ & $1.18^{\mathrm{cd}, \mathrm{x}}$ & $1.08^{\mathrm{abcd}, \mathrm{y}}$ & 0.02 & 0.002 \\
\hline $61-65$ & $1.13^{\mathrm{de}, \mathrm{x}}$ & $1.07^{\mathrm{abcd}, \mathrm{y}}$ & 0.01 & 0.021 \\
\hline $66-70$ & $1.16^{\text {cde, } x}$ & $1.08^{\mathrm{abcd}, \mathrm{y}}$ & 0.01 & $<0.001$ \\
\hline $71-75$ & $1.19^{c d, x}$ & $1.01^{\mathrm{cd}, \mathrm{y}}$ & 0.01 & $<0.001$ \\
\hline \multirow[t]{2}{*}{$76-80$} & $1.16^{\text {cde, } x}$ & $1.00^{\mathrm{d}, y}$ & 0.01 & $<0.001$ \\
\hline & \multicolumn{4}{|c|}{ Milk protein (kg/d per head) } \\
\hline $21-25$ & $1.12^{\mathrm{a}, \mathrm{x}}$ & $0.77^{\mathrm{abc}, y}$ & 0.04 & $<0.001$ \\
\hline $26-30$ & $1.11^{\mathrm{a}, \mathrm{x}}$ & $0.79^{\mathrm{a}, \mathrm{y}}$ & 0.02 & $<0.001$ \\
\hline $31-35$ & $1.05^{\mathrm{b}, \mathrm{x}}$ & $0.79^{a b, y}$ & 0.02 & $<0.001$ \\
\hline $36-40$ & $1.02^{b c, x}$ & $0.77^{a b c, y}$ & 0.01 & $<0.001$ \\
\hline $41-45$ & $0.98^{\text {cde, } x}$ & $0.75^{a b c, y}$ & 0.02 & $<0.001$ \\
\hline $46-50$ & $0.93^{f, x}$ & $0.73^{\mathrm{bc}, y}$ & 0.01 & $<0.001$ \\
\hline $51-55$ & $0.97^{\text {def,x }}$ & $0.78^{a b, y}$ & 0.01 & $<0.001$ \\
\hline $56-60$ & $0.99^{c d, x}$ & $0.76^{a b c, y}$ & 0.01 & $<0.001$ \\
\hline $61-65$ & $0.97^{\text {cdef }, x}$ & $0.78^{\mathrm{ab}, \mathrm{y}}$ & 0.01 & $<0.001$ \\
\hline $66-70$ & $1.00^{\mathrm{cd}, \mathrm{x}}$ & $0.76^{a b c, y}$ & 0.01 & $<0.001$ \\
\hline $71-75$ & $0.96^{\text {def,x }}$ & $0.74^{a b c, y}$ & 0.01 & $<0.001$ \\
\hline $76-80$ & $0.94^{\mathrm{ef}, \mathrm{x}}$ & $0.71^{c, y}$ & 0.01 & $<0.001$ \\
\hline
\end{tabular}

$\mathrm{THI}$, temperature-humidity index; SEM, standard error of the mean. a-f Denotes comparison made within the same column (comparison between THI and Holstein and Jersey cows, respectively) $(p<0.05)$.

${ }^{x, y}$ Denotes comparisons made with same row (comparison between the Holstein and Jersey cows in the same THI) $(p<0.05)$.

When THI exceeds 72, the cows begin to experience HS, while when THI is less than 38 , the cows begin to experience cold stress [13]. Among our study results, the average daily Ta exceeded $20^{\circ} \mathrm{C}$ on $8.65 \%$ of the time in the spring, $92.00 \%$ in the summer, and $24.65 \%$ in the autumn season. Also, average daily Ta $\leq 5$ was recorded on $10.10 \%$ in the spring, $11.97 \%$ in the autumn, and $96.41 \%$ in the winter season. The average $\mathrm{RH}$ of $>80 \%$ were higher in summer (23.21\%) and autumn (23.94\%), compared with the spring (7.21\%) and winter (13.17\%) season. The study results confirmed that the cows may suffer from both the heat and cold stress in spring and autumn season, particularly cows experienced the stress with higher $\mathrm{RH}(>80 \%)$ in autumn season than in spring season.

The average milk yield was reduced by $6.2 \%$ and $6.9 \%$ in Holstein and Jersey cows respectively as the average THI values changed from the spring to the autumn season and this lowered level may be due to the energy expenditure. Our study results are supported by Johnson et al [14] who re- ported early that the greater heat production can explain the increasing rate of decline in milk yield for cows. Also, the same authors explained that the permanent drop in the current lactation is proportional to the length of the HS. This study is consistent with earlier findings of Bohmanova et al [15] that the decline in milk production due to HS occurs with higher temperature in a semi-arid climate $\left(\geq 30^{\circ} \mathrm{C}, 25 \%\right.$ $\mathrm{RH})$ than in a humid climate $\left(\geq 23^{\circ} \mathrm{C}, 75 \% \mathrm{RH}\right)$.

Berman [16] reported that the higher milk yield is associated with HS, which by itself would shift lower critical temperature (LCT) to lower ambient temperatures. The LCT decreases in $-4^{\circ} \mathrm{C}[17]$ to values of $-30^{\circ} \mathrm{C}$ during peak lactation [18], $-37^{\circ} \mathrm{C}$ to $-16^{\circ} \mathrm{C}$ with $30 \mathrm{~kg} / \mathrm{d}$ of milk yield [19], $-40^{\circ} \mathrm{C}$ with $36 \mathrm{~kg} / \mathrm{d}$ of milk yield [20], or even $-45^{\circ} \mathrm{C}$ [21]. Milk yield could be affected between Holstein and Jersey cows in the range of LCT. Hence, the average milk yield in winter season was increased by $7.2 \%$ in Holstein cows compared to the autumn season; with the average THI and Ta being $35.29^{\circ} \mathrm{C}$ and $-1.49^{\circ} \mathrm{C}$, respectively. But, no significant difference was observed in Jersey cow's milk yield between the autumn and winter season.

In particular, the study results showed the different trends in the milk production of Holstein and Jersey cows, when the THI values increased from 16 to 80 . A negative regression slope line was observed in Holstein cow's milk production as THI increased from 16 to 80. Milk yield of Holstein and Jersey cows was reduced slightly (1\%) at THI range of 76 to 80 as compared with THI range of 66 to 70 . However, milk yields were increased by $15 \%$ in Holstein cows at the THI values of 16 to 20 , but milk yield was dropped by $11 \%$ in Jersey cows. Also, the milk yield dropped by $4 \%$ to $5 \%$ in Jersey cows, when THI values were between 21 and 50, and a loss of $11 \%$ when the THI values reached 16 to 20 . Our study results confirmed that the LCT and upper critical temperature affected the milk yield in Holstein and Jersey cows, particularly, Jersey cows experienced more cold stress than Holstein cows during each season in Korea.

The milk fat and protein content increased in Holstein cows when the THI value was 21 to 30 compared to Jersey cows ( 31 to 35 for milk fat and 26 to 30 for milk protein), and fat and protein content declined in Jersey cows more than in Holstein dairy cows, when the THI value was 76 to 80 and 46 to 50 respectively. Rodriquez et al [22] reported that HS environments have been associated with depressions in milk fat percentage. Bouraoui et al [23] suggested that the depressed fat percentage could be attributed to the decrease in forage intake of the diet, and TMR could alleviate milk fat depression associated with HS by maintaining the intended forage to concentrate intake and, ensuring adequate fiber for proper rumen function. Many studies reported that a decreased milk protein is associated with increased maximum daily temperature $[10,13]$. The reduction in milk protein 
is usually caused by a decreased dry matter intake and energy intake [13].

In practice, the yields of milk fat and protein in Holstein and Jersey cows were higher in the winter than in the other seasons. But in Holstein cows, it may be caused by increasing milk yield and milk fat and protein percentages as a result of adaptability to cold stress. However, in Jersey cows, it may be caused by decreasing milk yield as a result of a reduced resistance to cold stress.

\section{CONCLUSION}

According to the results obtained in the study, it was determined there were significant changes in each season's environment conditions. Also, the results of this study demonstrated that the seasonal changes affected the milk production and composition of Holstein and Jersey cows; also our study established the relationship between the THI and milk production between the Holstein and Jersey cows. Particularly, we observed significantly lowered milk production in autumn season by non-recovered HS from the summer season and high humidity in the autumn season. The milk production was negatively correlated with Holstein cows and positively correlated with Jersey cows with a THI of 16 to 80 . No significant changes were seen in milk yield between the Holstein and Jersey cows at THI of 76 to 80 . However, milk yield increased by $15 \%$ in Holstein cows and declined by $11 \%$ in Jersey cows at THI of 16 to 20. In addition, we found significantly higher percentage of milk fat and protein in Jersey cows than in Holstein cows. But, the yield of milk fat and protein content was higher in Holstein cows than in Jersey cows in all the THI ranges. Therefore, this study confirmed that Jersey cows were less adaptable to low temperature of the winter, which resulting in lower milk productivity. It seems to have a negative impact on dairy farmer income under Korea's milk price estimation system, which places a higher value on milk yield than on milk composition or sanitary grades. Further studies are needed to improve the adaptability of domestic breeding Jersey cows to a low temperature environment.

\section{CONFLICT OF INTEREST}

We certify that there is no conflict of interest with any financial organization regarding the material discussed in the manuscript.

\section{ACKNOWLEDGMENTS}

This study was supported by the Cooperative Research Program for Agricultural Science and Technology Development (Project Title: Development of feeding management tech- nology to increase the melatonin concentration of milk in dairy cattle; Project No: PJ01252001) of the Rural Development Administration of the Republic of Korea. The authors are grateful to the National Institute of Animal Science's Postdoctoral Research Associate Program of the Rural Development Administration of the Republic of Korea.

\section{REFERENCES}

1. Sejian V, Bhatta R, Soren NM, et al. Introduction to concepts of climate change impact on livestock and its adaptation and mitigation. In: Sejian V, Gaughan J, Baumgard L, Prasad C, editors. Climate change impact on livestock: adaptation and mitigation. New Delhi, India: Springer; 2015. pp. 1-23. https:// doi.org/10.1007/978-81-322-2265-1_1

2. Lee SM, Min SK. Heat stress changes over East Asia under $1.5^{\circ}$ and $2.0^{\circ} \mathrm{C}$ global warming targets. J Clim 2018;31:281931. https://doi.org/10.1175/JCLI-D-17-0449.1

3. Pragna P, Archana PR, Aleena J, et al. Heat stress and dairy cow: impact on both milk yield and composition. Int J Dairy Sci 2016.

4. Bland JH, Grandison AS, Fagan CC. Effect of blending Jersey and Holstein-Friesian milk on Cheddar cheese processing, composition, and quality. J Dairy Sci 2015;98:1-8. https:// doi.org/10.3168/jds.2014-8433

5. Jensen HB, Poulsen NA, Andersen KK, Hammershoj M, Poulsen HD, Larsen LB. Distinct composition of bovine milk from Jersey and Holstein-Friesian cows with good, poor, or noncoagulation properties as reflected in protein genetic variants and isoforms. J Dairy Sci 2012;95:6905-17. https://doi.org/10.3168/jds.2012-5675

6. Collier RJ, Eley RM, Sharma AK, Pereira RM, Buffington DE. Shade management in subtropical environment for milk yield and composition in Holstein and Jersey cows. J Dairy Sci 1981;64:844-9. https://doi.org/10.3168/jds.S00220302(81)82656-2

7. Mader TL, Davis MS, Brown-Brandl T. Environmental factors influencing heat stress in feedlot cattle. J Anim Sci 2006;84: 712-9. https://doi.org/10.2527/2006.843712x

8. Fox DG, Tylutki TP. Accounting for the effects of environment on the nutrient requirements of dairy cattle. J Dairy Sci 1998; 81:3085-95. https://doi.org/10.3168/jds.S0022-0302(98)758 73-4

9. Van Soeat PJ, Robertson JB, Lewis BA. Carbohydrate methodology, metabolism, and nutritional implications in dairy cattle: Methods for dietary fiber, neutral detergent fiber, and nonstrarch polysaccharides in relation to animal nutrition. J Dairy Sci 1991;74:3583-97. https://doi.org/10.3168/jds.S00220302(91)78551-2

10.Food and Agriculture Organization of the United Nations. Greenhouse gas emissions from the dairy sector. Rome, Italy: FAO; 2010. 
11. Roenfeldt S. You can't afford to ignore heat stress. Dairy Herd Manag 1998;35:6-12.

12. West JW, Mullinix BG, Bernard JK. Effects of hot, humid weather on milk temperature, dry matter intake, and milk yield of lactating dairy cows. J Dairy Sci 2003;86:232-42. https://doi.org/10.3168/jds.S0022-0302(03)73602-9

13. McDowell RE, Hooven NW, Camoens JK. Effect of climate on performance of Holsteins in first lactation. J Dairy Sci 1976;59:965-71. https://doi.org/10.3168/jds.S0022-0302(76) 84305-6

14. Johnson HD, Ragsdale AC, Berry IL, Shanklin MD. Effect of various temperature-humidity combinations on milk production of Holstein cattle. Columbia, MO, USA: University of Missouri; 1962.

15. Bohmanova J, Misztal I, Cole JB. Temperature-humidity indices as indicators of milk production losses due to heat stress. J Dairy Sci 2007;90:1947-56. https://doi.org/10.3168/ jds.2006-513

16. Berman A. Effects of body surface area estimates on predicted energy requirements and heat stress. J Dairy Sci 2003;86: 3605-10. https://doi.org/10.3168/jds.S0022-0302(03)73966-6

17. MacDonald MA, Bell JM. Effects of low fluctuating temperatures on farm animals: I. Influence of ambient air temperature on the respiration rate, heart rate, and rectal temperature of lactating Holstein-Friesian cows. Can J Anim Sci 1958;38:
10-22. https://doi.org/10.4141/cjas58-002

18. Young BA. Ruminant cold stress: effect on production. J Anim Sci 1983;57:1601-7. https://doi.org/10.2527/jas1983.5761 $601 x$

19. Kadzere CT, Murphy MR, Silanikove N, Maltz E. Heat stress in lactating dairy cows: a review. Livest Prod Sci 2002;77:5991. https://doi.org/10.1016/S0301-6226(01)00330-X

20. Webster AJF. Heat loss from cattle with particular emphasis on the effects of cold. In: Monteith JL, Mount LE, editors. Heat loss from animals and man: assessment and control. London, UK: Butterworths; 1974. pp. 205-31.

21. Christopherson RJ, Young BA. Effects of cold environments on domestic animals. In: Gudmundsson O, editor. Grazing research at northern latitudes. New York, USA: Plenum Press; 1986. pp. 247-57.

22. Rodriquez LA, Mekonnen G, Wilcox CJ, Martin FG, Krienke WA. Effects of relative humidity, maximum and minimum temperature, pregnancy, and stage of lactation on milk composition and yield. J Dairy Sci 1985;68:973-8. https:/doi.org/ 10.3168/jds.S0022-0302(85)80917-6

23. Bouraoui R, Lahmar M, Majdoub A, Djemali M, Belyea R. The relationship of temperature-humidity index with milk production of dairy cows in a Mediterranean climate. Anim Res 2002;51:479-91. https://doi.org/10.1051/animres:2002036 